\title{
STRES KERJA BERPENGARUH TERHADAP KINERJA PEGAWAI DENGAN MOTIVASI SEBAGAI MEDIASI DI DINAS PARIWISATA KLUNGKUNG
}

\author{
I Gede Yuma Adithya Mahaputra ${ }^{1}$ \\ I Komang Ardana ${ }^{2}$ \\ ${ }^{1,2}$ Fakultas Ekonomi dan Bisnis Universitas Udayana (Unud), Bali, Indonesia \\ email: igdyumaaditya@gmail.com
}

\begin{abstract}
ABSTRAK
Kinerja pegawai merupakan hasil kerja secara kuantitas maupun kualitas yang dicapai seorang pegawai dalam melaksanakan tugas sesuai dengan tanggung jawab yang telah diberikan. Tujuan penelitian ini adalah untuk mengetahui peran motivasi memediasi pengaruh stres kerja terhadap kinerja pegawai di Dinas Pariwisata Klungkung. Penelitian ini menggunakan sampel sebanyak 94 orang, dengan metode teknik sampling jenuh. Pengumpulan data dilakukan melalui observasi, wawancara dan kuesioner. Teknik analisis yang digunakan pada penelitian ini adalah analisis Jalur. Hasil penelitian ini menemukan bahwa stres kerja berpengaruh positif dan signifikan terhadap kinerja pegawai. Stres kerja berpengaruh positif dan signifikan terhadap motivasi. Motivasi berpengaruh positif dan signifikan terhadap kinerja pegawai. Motivasi memediasi pengaruh stres kerja terhadap kinerja pegawai. Implikasi dari hasil penelitian yaitu stres kerja dan motivasi secara nyata dapat meningkatkan kinerja pegawai, ketika stres yang dirasakan oleh pegawai dapat meningkatkan motivasi, maka motivasi yang dirasakan oleh pegawai menjadi semakin kuat sehingga berpotensi meningkatkan kinerja pegawai.
\end{abstract}

Kata kunci : kinerja karyawan, motivasi, stres kerja

\begin{abstract}
Employee performance is the result of work in quantity and quality achieved by employee in carrying out tasks that have been given. The purpose of this study was to determine the role of motivation to mediate the effect of work stress on employee performance in the Dinas Pariwisata Klungkung. 94 people were used as samle using saturated sampling. Data collected through observation, interviews and questionnaires. Path analysis was used. Work stress had positive and significant effect on employee performance. Job stress has a positive and significant effect on motivation. Motivation has positive and significant effect on employee performance. Motivation mediates the effect of work stress on employee performance. The implications of the study are work stress and motivation can significantly improve employee performance, when stress felt by employees can increase motivation, the motivation felt by employees becomes stronger so that it has the potential to improve employee performance.

Keywords: employee performance, motivation, work stress
\end{abstract}




\section{PENDAHULUAN}

Sektor pariwisata di Indonesia merupakan salah satu sektor yang menghasilkan devisa yang sangat besar bagi Negara Indonesia. Salah satu destinasi pariwisata yang terkenal di Indonesia yaitu Pulau Bali. Keindahan alam, adat, budaya dan agama yang masih di pertahankan dan di lestarikan masyarakat Bali adalah kunci utama dari eksistensi pariwisata di Bali yang menjadikan Bali sebagai destinasi pariwisata favorit bagi wisatawan domestik maupun mancanegara (Giantari \& Riana, 2017). Menurut data statistik dari Badan Pusat Statistik Provinsi Bali diketahui bahwa, perkembangan wisatawan asing yang berkunjung ke Bali 5 tahun terakhir mulai dari tahun 2014 sampai dengan 2018 adalah sebagai berikut.

Tabel 1.

Jumlah kunjungan wisatawan asing ke Bali tahun 2014 - 2018

\begin{tabular}{ccc}
\hline Tahun & Jumlah Wisatawan Asing (Orang) & Persentase (\%) \\
\hline 2014 & 3.766 .638 & 14,89 \\
2015 & 4.001 .835 & 6,27 \\
2016 & 4.927 .937 & 23,14 \\
2017 & 5.697 .739 & 15,62 \\
2018 & 6.070 .473 & 6,54 \\
\hline
\end{tabular}

Sumber : Data Diolah, 2019

Berdasarkan Tabel 1.diketahui bahwa jumlah kunjungan asing ke Bali dari tahun 2014-2018 terus mengalami perkembangan. Tahun 2014 mengalami peningkatan sebesar 14,89 persen, tahun 2014 ke 2015 sebesar 6,27 persen, tahun 2015 ke 2016 sebesar 23,14 persen, tahun 2016 ke 2017 sebesar 15,62 persen dan tahun 2017 ke 2018 sebesar 6,54 persen.

Perkembangan industri pariwisata suatu daerah sangat bergantung kepada jumlah wisatawan yang datang, karena itu harus ditunjang dengan peningkatan pemanfaatan Daerah Tujuan Wisata (DTW) sehingga industri pariwisata akan berkembang dengan baik. Pertumbuhan jumlah wisatawan di Bali tidak lepas dari semakin gencarnya promosi dan pelayanan yang dilakukan pemerintah pusat maupun daerah. Hal ini dapat dilihat dengan terbentuknya Dinas Pariwisata Provinsi Bali dan Dinas Pariwisata Kab./Kota yang bertujuan untuk pemanfaatan Daerah Tujuan Wisata (DTW) dan menciptakan destinasi wisata yang aman, nyaman, menarik dan mengoptimalkan sumberdaya alam yang khas sebagai pendukung terciptanya pariwisata yang berwawasan lingkungan.

Klungkung merupakan salah satu destinasi wisata dunia yang diakui memiliki keindahan alam dan budayanya yang unik. Klungkung memiliki banyak pantai yang indah, biasanya para wisatawan berkunjung untuk melihat keindahan objek wisata pantai serta menikmati keindahan sunrise dan sunset. Selain objek wisata pantai, Klungkung juga terkenal akan sungai yang jernih dan memiliki pemandangan yang indah serta masih banyak lagi objek wisata yang menarik seperti, wisata kuliner, wisata religi, wisata spiritual, wisata budaya, wisata sejarah dan wisata pertanian. Untuk dapat mengembangkan daerah Klungkung dan sektor wisatanya harus ditunjang dengan peningkatan pemanfaatan daerah tujuan wisata. 
Dinas Pariwisata Klungkung yang beralamat di Jl. Teratai No.4, Semarapura Kelod, Klungkung memiliki visi terwujudnya pariwisata dunia berbasis kemasyarakatan berdasarkan tri hita karana dalam meningkatkan kesejahteraan masyarakat dengan misi mengembangkan destinasi pariwisata yang aman, nyaman, menarik dengan mengedepankan keragaman potensi daya tarik wisata berdasarkan budaya Bali yang di jiwai oleh agama hindu, mengembangkan pemasaran pariwisata yang terpadu, efektif, efisien dan berkualitas, membangun sarana dan prasarana dalam keselarasan dan keharmonisan dan mengembangkan pelayanan yang baik kepada masyarakat. Untuk terwujudnya visi dan misi dari Dinas Pariwisata Kabupaten Klungkung tersebut harus di dukung oleh kinerja pegawai Dinas Pariwisata Kabupaten Klungkung.

Dinas Pariwisata Klungkung masih mendapatkan keluhan dari wisatawan mengenai kinerja pegawai Dinas Pariwisata Klungkung, seperti belum adanya infrastruktur untuk mengakses tempat wisata dengan mudah. Saat ini ada 15 objek pariwisata yang populer di Nusa Penida. Hanya saja, 10 di antaranya harus melalui jalan yang terjal dan melewati tebing - tebing curam serta belum tersedianya alat pengaman yang baik bagi wisatawan untuk mengurangi tingkat kecelakaan saat berkunjung ke tempat wisata. Keluhan yang lain adalah tentang penarikan retribusi juga muncul, penarikan retribusi ini berdasarkan Peraturan Daerah Nomor 5 Tahun 2018 tentang Perubahan Peraturan Daerah Nomor 3 Tahun 2013 tentang retribusi tempat rekreasi dan olahraga yang dilaksanakan mulai 1 Juli 2019. Penarikan retribusi ternyata telah menimbulkan kemacetan di lokasi penarikan retribusi seperti yang terjadi di Pelabuhan Banjar Nyuh.

Dalam upaya meningkatkan kinerja pegawai Dinas Pariwisata Klungkung telah menerapkan e-kinerja. E-kinerja adalah aplikasi berbasis web yang digunakan untuk menganalisis kebutuhan jabatan, beban kerja jabatan dan beban kerja unit/satuan kerja organisasi sebagai dasar perhitungan prestasi kerja dan pemberian insentif kerja. Setiap pegawai memperoleh penghasilan yang berbeda-beda setiap bulan sesuai dengan kinerja yang dicapai. Pegawai yang giat bekerja akan memperoleh pendapatan yang lebih besar dari pada pegawai yang malas.

Penerapan e-kinerja juga berfungsi untuk melecut motivasi kerja pegawai. Sumaryati (2009) motivasi kerja yang diberikan oleh perusahaan terhadap karyawan bisa dalam berbagai bentuk atau cara, salah satunya adalah memberikan insentif. Insentif merupakan suatu bentuk rangsangan yang dapat menjadikan seseorang lebih bergairah dalam bekerja dan produktif. Insentif dapat bersifat material, seperti pemberian tambahan uang lembur, gaji, upah atau barang kebutuhan sehari -hari. Insentif juga dapat bersifat immaterial, misalnya seperti pemberian kenaikan jabatan, piagam, penghargaan dan lainnya. Dari observasi yang telah dilakukan ternyata penerapan e-kinerja juga dapat menimbulkan stres kerja, seperti pegawai harus menyelesaikan tugas lebih banyak untuk mendapatkan penghasilan yang lebih banyak. Hal ini di dukung oleh pernyataan dari Notanubun et al. (2019) yang menyatakan bahwa faktor penyebab stres kerja diantaranya adalah stres karena peran atau tugas, penyebab stres antar pribadi seperti pegawai di kompetisikan untuk memenangkan reward dan kebijakan organisasi.

Kurniawan (2012) menyatakan kinerja karyawan sebagai prestasi kerja atau hasil kerja baik secara kualitas maupun kuantitas yang dicapai karyawan per 
periode dalam melaksanakan tugas sesuai dengan tanggung jawab yang diberikan kepada karyawan. Menurut Rahmanto \& Helina (2017) prestasi kerja atau kinerja karyawan sebagai tingkat pelaksanaan tugas yang dicapai oleh seseorang, unit, atau divisi, dengan menggunakan kemampuan yang ada dan batasan-batasan yang telah di tetapkan untuk mencapai tujuan perusahaan. Faktor - faktor yang mempengaruhi kinerja karyawan beragam, diantaranya : lingkungan kerja, motivasi, stres kerja, disiplin kerja , kepuasan kerja dan pengalaman kerja.

Motivasi adalah suatu daya pedorong yang menyebabkan orang berbuat sesuatu, agar karyawan dapat bekerja sesuai yang diharapkan maka dalam diri seorang karyawan harus memiliki motivasi kerja untuk dapat mencapai tujuan yang di inginkan. Rendahnya kinerja karyawan dapat disebabkan oleh masalah motivasi di dalam suatu perusahaan (Cemal et al., 2012). Penelitian tentang pengaruh motivasi terhadap kinerja karyawan sudah banyak dilakukan namun memberikan hasil yang beragam. Hasil penelitian dari Shahzadi et al. (2015) menemukan bahwa motivasi kerja berpengaruh positif terhadap kinerja karyawan, penelitian Asim (2013), Larasati \& Gilang (2014), Dwiputra \& Satrya (2019) menemukan hasil yang sama bahwa motivasi berpengaruh positif signifikan terhadap kinerja karyawan. Di sisi lain hasil penelitian Widyasari (2013), Hariasih \& Fahmi (2016) menemukan bahwa Motivasi kerja berhubungan negatif dan signifikan terhadap prestasi kerja karyawan, sementara peneletian Ijah (2013) menemukan bahwa motivasi kerja tidak berpengaruh terhadap kinerja karyawan.

Stress adalah kondisi ketegangan yang mempengaruhi emosi, proses berpikir dan kondisi seseorang. Penelitian tentang pengaruh stres kerja terhadap kinerja karyawan juga sudah banyak dilakukan, namun memberikan hasil yang beragam, Kotteeswari \& Sharief (2015) menemukan bahwa tedapat pengaruh negatif antara stres kerja dengan kinerja karyawan. Penelitian Notanubun et al. (2019) menemukan bahwa stres kerja tidak berpengaruh signifikan terhadap prestasi kerja. Sedangkan penelitian Roring \& Dotoulong (2014) menemukan bahwa stres kerja secara statistik berpengaruh positif dan signifikan terhadap prestasi kerja. Sementara penelitian Komarudin (2018) dan Massie \& Areros (2018) memperoleh hasil bahwa terdapat hubungan positif antara stres kerja terhadap kinerja karyawan dan penelitian Zafar et al. (2015), Karim (2014) menemukan hasil yang sama bahwa terdapat hubungan positif signifikan antara stres kerja terhadap kinerja karyawan.

Penelitian mengenai hubungan motivasi, stres kerja dengan kinerja karyawan juga menghasilkan hal yang beragam. Penelitian yang dilakukan oleh Zeb Alam \& Rehman (2015) menemukan adanya pengaruh positif antara stres kerja terhadap motivasi kerja karyawan, sedangkan penelitian dari Ratnawat \& Jha (2014) menemukan bahwa stres kerja mempunyai pengaruh negatif dan signifikan terhadap motivasi kerja karyawan, di sisi lain hasil penelitian Noermijati \& Primasari (2015), Cendhikia et al. (2016) menemukan hasil yang sama bahwa stres kerja berpengaruh positif dan signifikan terhadap motivasi dan kinerja karyawan.

Tujuan penelitian ini adalah untuk menganalisis pengaruh stres kerja terhadap kinerja pegawai di Dinas Pariwisata Klungkung, menganalisis pengaruh stres kerja terhadap motivasi pegawai di Dinas Pariwisata Klungkung, menganalisis pengaruh motivasi terhadap kinerja pegawai di Dinas Pariwisata Klungkung dan 
menganalisis pengaruh stres kerja terhadap kinerja pegawai di Dinas Pariwisata Klungkung dengan mediasi motivasi.

Teori yang digunakan dalam penelitian ini adalah teori pertukaran sosial (social exchange theory). Social exchange theory atau teori pertukaran sosial digunakan para peneliti organisasi sebagai kerangka yang memiliki pengaruh untuk menjelaskan perilaku kerja seseorang (Cropanzano et al., 2017). Kegiatan tukarmenukar tersebut dapat memperkuat hubungan antar pihak yang terlibat dalam hubungan pertukaran, yang pada akhirnya menghasilkan perilaku yang produktif (Walden et al., 2018). Seseorang dalam hubungan pertukaran dengan orang lain akan mengharapkan imbalan yang diterima oleh setiap pihak sesuai dengan pengorbanan yang telah di keluarkannya, makin tinggi pengorbanan, makin tinggi keuntungan yang diterima oleh setiap pihak.

Teori ini adalah pandangan bahwa interaksi sosial digambarkan melalui tukar-menukar yang terjadi di antara anggota kelompok yang dengan pengorbanan mereka masing-masing dapat memberikan kontribusi dan dengan pengorbanan dari anggota atau kelompok dapat menerima imbalan. Interaksi akan berlangsung secara terus menerus, dan dilakukan oleh seluruh anggota yang ada di organisasi, karena merasa kegiatan tukar-menukar secara sosial ini mampu saling memberikan keuntungan. Dengan begitu pemimpin (leader) dan yang dipimpin (follower), serta anggota lainnya mampu melakukan tukar-menukar sosial yang saling menguntungkan dengan saling memberi dan menerima (Arrasyid et al., 2019).

Seorang pemimpin harus mampu menggerakan seluruh anggota organisasi. Gerakan tersebut dapat terjadi apabila terdapat hubungan yang saling menguntungkan di dalam suatu organisasi. Teori ini menekankan adanya hubungan memberi (give) dan menerima (take) di antara pemimpin dan anggota dari organisasi yang dipimpinnya. Teori pertukaran sosial ini juga sering di katakan sebagai teori saling memberi dan menerima (Nazir et al., 2018). Ketika karyawan menerima perlakuan yang adil oleh pimpinan, mereka akan memikirkan hubungan dengan pimpinan dalam hal pertukaran sosial daripada pertukaran ekonomi. Selanjutnya, mereka akan memberikan usaha ekstra ke dalam pekerjaan dan tanggung jawab yang diberikan.

Menurut Zameer et al. (2015), kinerja karyawan merupakan hasil yang dicapai karyawan atas kerja yang dilakukan. Kinerja karyawan merupakan seberapa banyak karyawan berkontribusi kepada perusahaan meliputi kuantitas output, jangka waktu, kehadiran di tempat kerja. Stress kerja berpengaruh terhadap motivasi dan kinerja pegawai. Pengaruh stres kerja terhadap kinerja pegawai dapat merupakan suatu pengaruh tidak langsung. Karena stres kerja dapat mempengaruhi salah satu faktor kinerja pegawai yaitu motivasi. Motivasi kerja sangat dibutuhkan oleh pegawai sebagai dorongan untuk menciptakan semangat dan gairah kerja.

Stres yang terlalu tinggi dapat mengganggu pegawai dalam melaksanakan tugas dan pekerjaan yang dibebankan pada pegawai sehingga dapat berakibat pada kemampuan pegawai untuk menyelesaikan tugas. Stres yang berlebihan juga dapat mengakibatkan menurunya motivasi, motivasi yang rendah dapat mengakibatkan kinerja pegawai semakin menurun. Noermijati \& Primasari (2015) menemukan bahwa stres kerja mempengaruhi motivasi dan kinerja karyawan secara signifikan 
dan penelitian dari Naradhipa \& Asshuri (2016) menemukan hasil bahwa stres kerja mempengaruhi kinerja karyawan melalui motivasi kerja sebagai variabel intervening. Berdasarkan permasalahan yang telah dikemukakan, kajian teoritis, dan tinjauan penelitian terdahulu dapat digambarkan kerangka konseptual seperti pada gambar 1 .

Stress adalah kondisi ketegangan yang mempengaruhi emosi, proses berpikir dan kondisi seseorang. Stres kerja yang berlebihan dapat mengganggu kinerja pegawai dan akan merugikan perusahaan. Dampak stres tersebut dapat berupa rendahnya tingkat produktivitas, minimnya kreativitas, kurangnya motivasi, pengambilan keputusan yang tidak efektif dan tingkat absensi/ketidakhadiran pegawai yang tinggi. Penelitian dari Komarudin (2018), Massie \& Areros (2018), Zafar et al. (2015) menemukan hasil yang sama bahwa terdapat hubungan positif signifikan antara stres kerja terhadap kinerja karyawan. Roring \& Dotoulong (2014), Karim (2014) dalam penelitiannya menemukan hasil yang sama bahwa stres kerja secara statistik berpengaruh positif dan signifikan terhadap prestasi kerja karyawan. Berdasarkan uraian tersebut maka hipotesis yang diajukan dalam penelitian ini adalah :

$\mathrm{H}_{1}$ : Stres kerja berpengaruh positif dan signifikan terhadap kinerja pegawai di Dinas Pariwisata Klungkung

Stres adalah kondisi ketegangan yang mempengaruhi emosi, proses berpikir dan kondisi seseorang. Motivasi adalah suatu daya pedorong yang menyebabkan orang berbuat sesuatu. Motivasi kerja sangat dibutuhkan oleh pegawai sebagai dorongan untuk menciptakan semangat dan gairah kerja. Stres kerja dapat menyebabkan menurunnya motivasi kerja dan kinerja pegawai. Penelitian yang telah dilakukan oleh Zeb Alam \& Rehman (2015) menemukan adanya pengaruh positif antara stres kerja terhadap motivasi kerja karyawan. Penelitian dari Noermijati \& Primasari (2015), Pertiwiningsih \& Puspasari (2014), Rendika \& Setyawan (2015), Cendhikia et al. (2016) menemukan hasil yang sama bahwa stres kerja berpengaruh postif dan signifikan terhadap motivasi. Berdasarkan uraian tersebut maka hipotesis yang diajukan dalam penelitian ini adalah:

$\mathrm{H}_{2}$ : Stres kerja berpengaruh positif dan signifikan terhadap motivasi pegawai di

Dinas Pariwisata Klungkung

Motivasi pada seseorang dapat mengakibatkan tumbuhnya semangat dan gairah kerja, jika semangat kerja menjadi tinggi maka pekerjaan yang dibebankan kepada pegawai akan lebih cepat dan tepat diselesaikan. Pekerjaan yang dengan cepat dan tepat selesai merupakan suatu prestasi kerja pegawai. Penelitian Mohamud et al. (2017), Ali et al. (2016), Ekundayo \& Babalola (2018) menemukan hasil yang sama bahwa terdapat hubungan positif dan signifikan antara motivasi kerja dengan kinerja karyawan. Shahzadi et al. (2015) menemukan bahwa terdapat pengaruh positif antara motivasi kerja dengan kinerja karyawan. Dwiputra \& Satrya (2019) menemukan bahwa motivasi kerja berpengaruh signifikan terhadap kinerja karyawan. Berdasarkan uraian tersebut maka hipotesis yang diajukan dalam penelitian ini adalah :

$\mathrm{H}_{3}$ : Motivasi berpengaruh positif dan signifikan terhadap kinerja pegawai di Dinas Pariwisata Klungkung 
Pengaruh stres kerja terhadap kinerja pegawai dapat berupa pengaruh tidak langsung. Karena stres kerja dapat mempengaruhi salah satu faktor kinerja yaitu motivasi. Stres yang terlalu tinggi dapat mengakibatkan menurunya motivasi, motivasi yang rendah dapat mengakibatkan kinerja pegawai semakin menurun. Banyak faktor yang dapat menyebabkan terjadinya stres kerja, dari berbagai kajian empiris ditemukan bahwa stres kerja berpengaruh terhadap motivasi dan kinerja pegawai. Mariati (2018), Noermijati \& Primasari (2015), Cendhikia et al. (2016), Maulidyah (2017) menemukan hasil yang sama bahwa stres kerja berpengaruh positif dan signifikan terhadap motivasi dan kinerja karyawan. Berdasarkan uraian tersebut maka hipotesis yang diajukan dalam penelitian ini adalah:

$\mathrm{H}_{4}$ : Motivasi memediasi pengaruh stres kerja terhadap kinerja pegawai di Dinas Pariwisata Klungkung.



Gambar 1. Kerangka Konseptual

\section{METODE PENELITIAN}

Penelitian ini menggunakan pendekatan asosiatif. Karena penelitian ini bertujuan untuk menguji pengaruh antar variabel penelitian. Dalam penelitian ini variabel yang di teliti yaitu kinerja pegawai (Y) sebagai variabel terikat, motivasi (M) sebagai variabel mediasi, dan stres kerja $\left(\mathrm{X}_{1}\right)$ sebagai variabel bebas. Penelitian ini dilakukan di Dinas Pariwisata Klungkung yang beralamat di Jl. Teratai No.4, Semarapura Kelod, Klungkung, Bali, Indonesia Adapun obyek dari penelitian ini adalah kinerja pegawai, motivasi, dan stres kerja pegawai di Dinas Pariwisata Klungkung. Variabel terikat dalam penelitian ini adalah kinerja pegawai. Variabel mediasi dalam penelitian ini adalah motivasi. Variabel bebas dalam penelitian ini adalah stres kerja

Dalam penelitian ini yang dimaksud kinerja pegawai adalah hasil kerja yang dicapai oleh pegawai dari tugas dan pekerjaan yang diberikan sesuai dengan standar prilaku yang ditetapkan oleh Dinas Pariwisata Klungkung. Indikator - indikator untuk mengukur kinerja pegawai dalam penelitian ini (Koopmans et al., 2015) 
adalah sebagai berikut : 1) Kinerja tugas (Task performance), berkaitan dengan perilaku pegawai yang ditunjukan dengan penyelesaian kerja sesuai dengan rencana, tepat waktu dan juga optimal. Diukur melalui persepsi responden mengenai merencanakan pekerjaan sehingga selesai tepat waktu, optimal, menargetkan hasil yang harus dicapai dan dapat memisahkan masalah utama dengan masalah sampingan di tempat kerja. 2) Kinerja kontekstual (Contextual performance), berkaitan dengan kinerja pegawai yang dapat dilihat dari tujuan yang akan dicapai, profesionalitas pegawai di tempat kerja, kesadaran dan keinginan untuk memberikan kontribusi lebih tinggi bagi organisasi di luar tugas fungsi dan pokoknya sesuai jabatan. Diukur melalui persepsi responden mengenai mengambil tanggung jawab ekstra, memulai tugas baru ketika tugas lama selesai, mengambil pekerjaan menantang dan menghadapi masalah baru dengan solusi kreatif (Mardyana \& Riana, 2019).

Motivasi adalah suatu daya pedorong yang menyebabkan seseorang berbuat sesuatu. Supaya pegawai dapat bekerja sesuai yang diharapkan, maka dalam diri seorang pegawai harus ditumbuhkan motivasi bekerja untuk mencapai tujuan yang diinginkan (Putra \& Suwandana, 2018). Indikator yang dinilai dalam stres kerja adalah (Diputra \& Surya, 2019): Beban kerja, Waktu kerja dan Wewenang / Tanggung jawab

Didalam penelitian ini adalah data jumlah pegawai dan data hasil kuesioner. Sumber primer berupa data yang dapat diperoleh secara langsung dari Dinas Pariwisata Klungkung dengan menggunakan kuesioner dan wawancara, dimana dalam wawancara peneliti mendapat jawaban langsung dari responden dan melalui kuesioner responden memberikan skor pada variabel - variabel penelitian dalam kuesioner. Sumber sekunder berupa data yang sudah dalam bentuk jadi atau dapat dikatakan data yang sudah tersedia di Dinas Pariwisata Klungkung, contohnya seperti data jumlah pegawai dan data - data Dinas Pariwisata Klungkung yang diperlukan dalam penelitian ini. Populasi dalam penelitian ini adalah semua pegawai di Dinas Pariwisata Klungkung yang berjumlah 94 orang. Pada penelitian ini, menggunakan nonprobability sampling dengan jenis teknik sampling jenuh atau sensus. Jadi, seluruh pegawai dalam populasi sejumlah 94 orang akan di teliti karena jumlahnya tidak terlalu besar.

Metode pengumpulan data yang digunakan adalah sebagai berikut : 1) Metode Observasi Partisipan untuk mengamati secara langsung bagaimana kondisi kinerja pegawai, motivasi dan stres kerja pegawai di Dinas Pariwisata Klungkung. 2) Wawancara dalam penelitian ini adalah metode pengumpulan data dengan tanya jawab secara langsung dengan pegawai Dinas Pariwisata Klungkung. Pertanyaan dalam wawancara meliputi permasalahan ataupun keluhan pegawai yang berkaitan dengan Job description, motivasi, stres kerja dan kinerja pegawai Dinas Pariwisata Klungkung. 3) Kuesioner dapat berupa pertanyaan/pernyataan tertutup atau terbuka dapat diberikan kepada responden secara langsung atau dikirim melalui pos atau internet. Kuesioner penelitian ini diukur dengan menggunakan skala Likert, yaitu pilihan jawaban responden di beri nilai dengan skala lima poin. 


\section{HASIL DAN PEMBAHASAN}

Kantor Dinas Pariwisata Klungkung yang beralamat di Jl. Teratai, No. 4, Semarapura Kelod, Klungkung ini memiliki tugas untuk, melaksanakan urusan pemerintahan Kabupaten Klungkung dalam bidang pariwisata berdasarkan asas otonomi daerahnya. Melalui Dinas Pariwisata Klungkung atau yang disingkat Dispar Klungkung ini, berbagai urusan pemerintah daerah terkait bidang pariwisata dilakukan. Adapun tugas Dispar Klungkung adalah sebagai pelaksana urusan pemerintah daerah pada bidang pariwisata di wilahnya kerjanya. Fungsi Dispar Klungkung ialah merumuskan kebijakan bidang pariwisata, kesenian, kebudayaan, pembinaan dan pembimbingan pada pelaku pariwisata dan budaya di wilayah kerjanya hingga pelaporan dan koordinasi urusan pariwisata dan budaya.

Dinas Pariwisata Klungkung saat ini dipimpin oleh seorang kepala dinas yaitu Drs. I Nengah Sukasta. M.Si. Terkait dengan tugas dan fungsinya, Dispar Klungkung berwenang untuk mengeluarkan izin-izin bidang pariwisata meliputi Izin Usaha Pariwisata untuk travel agent dan lainnya, mengurus Izin Tetap Usaha Pariwisata (ITUP), Tanda Daftar Usaha Pariwisata atau TDUP meliputi surat Tanda Daftar Usaha Jasa Perjalanan Wisata, Tanda Daftar Usaha Penyedia Akomodasi, Tanda daftar Usaha Kawasan Pariwisata, dan lainnya.

Data karakteristik responden adalah data responden yang di kumpulkan untuk mengetahui profil responden penelitian. Berdasarkan hasil penelitian yang dilakukan terhadap pegawai Di Dinas Pariwisata Klungkung dapat diketahui karakteristik respondennya meliputi jenis kelamin, usia dan pendidikan terakhir yang dijelaskan pada Tabel 2 .

Tabel 2.

Karakteristik Responden

\begin{tabular}{|c|c|c|c|c|}
\hline No & Variabel & Klasifikasi & Jumlah (orang) & $\begin{array}{l}\text { Persentase } \\
(\%)\end{array}$ \\
\hline \multirow{3}{*}{1} & \multirow{2}{*}{ Jenis Kelamin } & Laki - Laki & 59 & 62.77 \\
\hline & & Perempuan & 35 & 37.23 \\
\hline & Jumlah & & 94 & 100 \\
\hline \multirow{5}{*}{2} & \multirow{4}{*}{ Usia } & 19-24 Tahun & 26 & 27.66 \\
\hline & & 25-34 Tahun & 38 & 40.43 \\
\hline & & 35-40 Tahun & 18 & 19.15 \\
\hline & & > 40Tahun & 12 & 12.77 \\
\hline & Jumlah & & 94 & 100 \\
\hline \multirow{4}{*}{3} & Pendidikan & SMA & 10 & 10.64 \\
\hline & terakhir & Diploma & 38 & 40.43 \\
\hline & & $\mathrm{S} 1$ & 46 & 48.94 \\
\hline & Jumlah & & 94 & 100 \\
\hline
\end{tabular}

Sumber : Data Diolah, 2019

Jumlah pegawai Di Dinas Pariwisata Klungkung yang di jadikan sampel sebanyak 94 orang. Jika di lihat dari jenis kelamin, jenis kelamin laki-laki mendominasi dalam penelitian ini dengan presentase sebesar 62,77 persen. Jika di lihat dari usia, yang memiliki usia 25-34 tahun mendominasi dengan presentase 
sebesar 40,43 persen. Jika di lihat dari tingkat pendidikan yang memiliki tingkat pendiddikan terakhir S1 yang mendominasi dengan persentase sebesar 48,94 persen.

Tabel 3.

Rekapitulasi Hasil Uji Validitas Instrumen Penelitian

\begin{tabular}{|c|c|c|c|}
\hline No. & Variabel & Instrumen & Pearson Correlation \\
\hline \multirow{3}{*}{1.} & \multirow{3}{*}{ Stres kerja $(\mathrm{X})$} & $\mathrm{X} 1$ & 0,932 \\
\hline & & $\mathrm{X} 2$ & 0,927 \\
\hline & & $\mathrm{X} 3$ & 0,908 \\
\hline \multirow{3}{*}{2.} & \multirow{3}{*}{ Motivasi (M) } & M1 & 0,960 \\
\hline & & M2 & 0,932 \\
\hline & & M3 & 0,916 \\
\hline \multirow{8}{*}{3.} & \multirow{8}{*}{ Kinerja pegawai (Y) } & Y1 & 0,863 \\
\hline & & $\mathrm{Y} 2$ & 0,891 \\
\hline & & Y3 & 0,929 \\
\hline & & Y4 & 0,904 \\
\hline & & Y5 & 0,911 \\
\hline & & Y6 & 0,848 \\
\hline & & Y7 & 0,711 \\
\hline & & Y8 & 0,747 \\
\hline
\end{tabular}

Sumber : Data Diolah, 2019

Seluruh instrumen variabel penelitian stres kerja, motivasi dan kinerja pegawai telah memenuhi syarat uji validitas yang dimana nilai skor total Pearson Correlation masing-masing instrumen berada diatas 0,30 dan memiliki nilai signifikansi yang lebih kecil dari 5 persen $(0,05)$, maka instrumen layak digunakan menjadi alat ukur variabel-variabel tersebut.

Tabel 4.

Hasil Uji Reliabilitas Instrumen Penelitian

\begin{tabular}{lll}
\hline No. & Variabel & Cronbach's Alpha \\
\hline 1. & Stres kerja $(\mathrm{X})$ & 0,911 \\
3. & Motivasi $(\mathrm{M})$ & 0,928 \\
4. & Kinerja pegawai $(\mathrm{Y})$ & 0,944 \\
\hline Sumber & Data &
\end{tabular}

Sumber : Data Diolah, 2019

Uji reliabilitas pada masing-masing variabel berada pada titik diatas 0,60 yang ditunjukkan pada hasil Cronbach's Alpha, maka dapat di katakan seluruh instrumen telah memenuhi syarat reliabilitas.

Dapat dilihat dari persepsi responden bahwa rata - rata kinerja pegawai di Dinas Pariwisata Klungkung masuk dalam kategori cukup baik. Variabel kinerja pegawai yang memiliki rata-rata terendah adalah pernyataan "Rencana kerja saya berjalan optimal ", diperoleh nilai rata-rata sebesar 3,14 yang masuk kriteria cukup baik, tetapi memiliki nilai rata-rata yang rendah dibandingkan dengan pernyataan yang lainnya ini berarti secara umum rencana kerja responden belum berjalan optimal. Variabel kinerja pegawai yang memiliki rata-rata tertinggi adalah 
pernyataan "Saya memulai tugas (pekerjaan) baru, ketika tugas lama selesai", diperoleh nilai rata-rata sebesar 3,33 yang masuk kriteria cukup baik, ini berarti secara umum responden memulai tugas (pekerjaan) baru, ketika tugas lama selesai.

Persepsi responden mengenai variabel motivasi. Dapat dilihat dari persepsi responden bahwa rata - rata motivasi pegawai di Dinas Pariwisata Klungkung masuk dalam kategori cukup, adapun yang memiliki rata-rata tertinggi dan terendah adalah variabel motivasi yang memiliki rata-rata terendah adalah pernyataan "Saat saya melakukan kesalahan dalam melakukan pekerjaan, saya akan berinisiatif memperbaiki menjadi lebih baik", diperoleh nilai rata-rata sebesar 3,18 yang masuk kriteria cukup, tetapi memiliki nilai rata-rata yang rendah dibandingkan dengan pernyataan yang lainnya ini berarti secara umum responden menganggap saat responden melakukan kesalahan dalam melakukan pekerjaan, responden tidak berinisiatif memperbaiki menjadi lebih baik. Variabel motivasi yang memiliki ratarata tertinggi adalah pernyataan "Saya selalu mentaati peraturan yang di tetapkan oleh perusahaan dan saya selalu berusaha serius pada pekerjaan yang selalu saya lakukan ", diperoleh nilai rata-rata sebesar 3,32 yang masuk kriteria cukup, ini berarti secara umum responden selalu mentaati peraturan yang ditetapkan oleh perusahaan dan selalu berusaha serius pada pekerjaan yang dilakukan.

Persepsi responden mengenai variabel stres kerja. Dapat dilihat dari persepsi responden bahwa rata - rata stres kerja pegawai di Dinas Pariwisata Klungkung masuk dalam kategori cukup, adapun yang memiliki rata-rata tertinggi dan terendah adalah variabel stres kerja yang memiliki rata-rata terendah adalah pernyataan "Saya mampu menyelesaikan pekerjaan dengan tepat waktu", diperoleh nilai rata-rata sebesar 3,26 yang masuk kriteria cukup, tetapi memiliki nilai ratarata yang rendah dibandingkan dengan pernyataan yang lainnya ini berarti secara umum responden menganggap belum mampu menyelesaikan pekerjaan dengan tepat waktu. Variabel stres kerja yang memiliki rata-rata tertinggi adalah pernyataan "Saya bersedia menanggung semua konsekuensi yang diberikan bila lalai dalam menyelesaikan pekerjaan", diperoleh nilai rata-rata sebesar 3,36 yang masuk kriteria cukup, ini berarti secara umum responden bersedia menanggung semua konsekuensi yang diberikan bila lalai dalam menyelesaikan pekerjaan.

Tabel 5.

Hasil Analisis Jalur Pada Struktur 1

\begin{tabular}{|c|c|c|c|c|c|}
\hline \multirow[t]{2}{*}{ Model } & \multicolumn{2}{|c|}{ Unstandardized Coefficients } & \multirow{2}{*}{$\begin{array}{l}\text { Standardized } \\
\text { Coefficients } \\
\text { Beta } \\
\end{array}$} & \multirow[t]{2}{*}{$\mathbf{t}$} & \multirow[t]{2}{*}{ Sig. } \\
\hline & B & Std. Error & & & \\
\hline (Constant) & 3.357 & 0.856 & & 3.920 & 0.000 \\
\hline Stres kerja & 0.651 & 0.084 & 0.630 & 7.776 & 0.000 \\
\hline$\overline{\mathrm{R}^{2}}$ & & & & & \\
\hline
\end{tabular}

Berdasarkan hasil analisis jalur pada Tabel 5. maka dapat dirumuskan persamaan struktural yang terbentuk adalah sebagai berikut.

$\mathrm{M}=\rho_{1} \mathrm{X}+\mathrm{e}_{1}$

$\mathrm{M}=0,630 \mathrm{X}+\mathrm{e} 1$. 
Persamaan struktural tersebut dapat diartikan yaitu variabel stres kerja memiliki koefisien sebesar 0,630 berarti stres kerja memiliki pengaruh positif terhadap motivasi, ini diartikan apabila stres kerja meningkat maka motivasi akan meningkat sebesar 0,630 atau 63 persen.

Tabel 6.

Hasil Analisis Jalur Pada Struktur 2

\begin{tabular}{llllll}
\hline \multirow{2}{*}{ Model } & \multicolumn{2}{l}{$\begin{array}{l}\text { Unstandardized } \\
\text { Coefficients }\end{array}$} & $\begin{array}{l}\text { Standardized } \\
\text { Coefficients }\end{array}$ & t & Sig. \\
\cline { 2 - 5 } & B & Std. Error & Beta & \\
\hline (Constant) & 4.641 & 1.490 & & 3.115 & 0.002 \\
Stres kerja & 1.443 & 0.074 & 0.611 & 8.315 & 0.000 \\
Motivasi & 0.702 & 0.068 & 0.307 & 4.181 & 0.000 \\
\hline $\mathrm{R}^{2}$ & $: 0.704$ & & & & \\
\hline Sumber : Data Diolah, 2019 & &
\end{tabular}

Berdasarkan hasil analisis jalur pada Tabel 6 maka dapat dirumuskan persamaan struktural yang terbentuk adalah sebagai berikut.

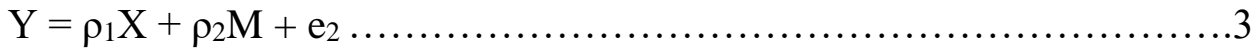

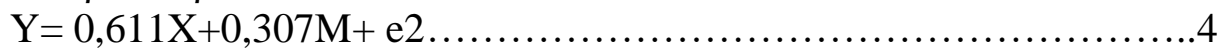

Variabel stres kerja memiliki koefisien sebesar 0,611 berarti stres kerja memiliki pengaruh positif terhadap kinerja pegawai, ini diartikan apabila stres kerja meningkat maka kinerja pegawai akan meningkat sebesar 0,611 atau 61,1 persen. Variabel motivasi memiliki koefisien sebesar 0,307 berarti motivasi memiliki pengaruh positif terhadap kinerja pegawai, ini diartikan apabila motivasi meningkat maka kinerja pegawai akan meningkat sebesar 0,307 atau 30,7 persen.

Pada perhitungan nilai koefisien determinasi total di dapatkan sebesar 0,822, maka kesimpulannya adalah 82,2 persen variabel kinerja pegawai di Dinas Pariwisata Klungkung dipengaruhi oleh stres kerja, dan motivasi, sedangkan sisanya 17,8 persen di pengaruhi oleh faktor lain yang tidak di masukkan dalam model penelitian atau di luar model penelitian. Stres kerja memiliki nilai Beta sebesar 0,611 dan nilai Sig. sebesar 0,000, maka dapat dikatakan $\mathrm{H}_{1}$ diterima karena nilai Sig. 0,000 < 0,05. Kesimpulannya adalah stres kerja berpengaruh positif dan signifikan terhadap kinerja pegawai dengan kata lain semakin meningkat stres kerja maka kinerja pegawai di Dinas Pariwisata Klungkung akan semakin meningkat. Sehingga hipotesis pertama diterima. Stres kerja memiliki nilai Beta sebesar 0,630 dan nilai Sig. sebesar 0,000, maka dapat dikatakan $\mathrm{H}_{2}$ diterima karena nilai Sig. 0,000 < 0,05. Kesimpulannya adalah bahwa stres kerja memiliki pengaruh positif dan signifikan terhadap motivasi, dengan kata lain semakin meningkat stres kerja pegawai di Dinas Pariwisata Klungkung, maka semakin meningkat motivasi pegawai di Dinas Pariwisata Klungkung. Sehingga hipotesis kedua diterima. 
Motivasi memiliki nilai Beta sebesar 0,307 dan nilai Sig. sebesar 0.000, maka dapat dikatakan $\mathrm{H}_{3}$ diterima karena nilai Sig. $0.000<0,05$. Kesimpulannya adalah bahwa motivasi memiliki pengaruh positif dan signifikan terhadap kinerja pegawai, dengan kata lain apabila motivasi meningkat maka kinerja pegawai di Dinas Pariwisata Klungkung akan meningkat. Sehingga hipotesis ketiga diterima.

Tabel 7.

Pengaruh Langsung, Pengaruh Tidak Langsung Stres kerja(X), Terhadap

Motivasi (M) dan Kinerja pegawai (Y).

\begin{tabular}{cccc}
\hline Pengaruh variabel & $\begin{array}{c}\text { Pengaruh } \\
\text { langsung }\end{array}$ & $\begin{array}{c}\text { Pengaruh tidak } \\
\text { langsung melalui } \mathbf{M}\end{array}$ & Pengaruh Total \\
\hline $\mathrm{X} \rightarrow \mathrm{M}$ & 0,630 & & 0,630 \\
$\mathrm{M} \rightarrow \mathrm{Y}$ & 0,307 & 0,193 & 0,307 \\
$\mathrm{X} \rightarrow \mathrm{Y}$ & 0,611 & & 0,804 \\
\hline
\end{tabular}

Sumber : Data Diolah, 2019

Pada penelitian yang dilakukan di Dinas Pariwisata Klungkung. Tentang pengaruh stres kerja terhadap motivasi, maka didapatkan hasil stres kerja memiliki pengaruh langsung terhadap motivasi dengan persentase sebesar 0,630 atau 63 persen.Pada penelitian yang dilakukan di Dinas Pariwisata Klungkung. Tentang pengaruh motivasi terhadap kinerja pegawai, maka di dapatkan hasil motivasi memiliki pengaruh langsung terhadap kinerja pegawai dengan persentase sebesar 0,307 atau 30,7 persen. Pada penelitian yang dilakukan di Dinas Pariwisata Klungkung. Tentang pengaruh stres kerja terhadap kinerja pegawai, maka di dapatkan hasil stres kerja memiliki pengaruh langsung terhadap kinerja pegawai dengan persentase sebesar 0,611 atau 61,1 persen. Pada penelitian yang dilakukan di Dinas Pariwisata Klungkung.

Tentang peran motivasi dalam memediasi pengaruh stres kerja terhadap kinerja pegawai, maka di dapatkan hasil bahwa stres kerja memiliki pengaruh langsung dan tidak langsung melalui motivasi terhadap kinerja pegawai dengan nilai koefisien masing-masing sebesar 0,611 dan 0,193, sehingga besaran pengaruh totalnya adalah 0,804 atau 80,4 persen. Berdasarkan hasil uji sobel menunjukkan bahwa hasil tabulasi $\mathrm{Z}=3,843>1,96$ hal ini menunjukan bahwa motivasi (M) merupakan variabel yang memediasi stres kerja (X) terhadap kinerja pegawai (Y) atau dengan kata lain stres kerja berpengaruh secara tidak langsung terhadap kinerja pegawai melalui motivasi. Sehingga hipotesis keempat diterima.

Hasil pengujian hipotesis dalam penelitian ini menunjukkan bahwa stres kerja berpengaruh positif dan signifikan terhadap kinerja pegawai dengan kata lain semakin tinggi stres kerja maka kinerja pegawai di Dinas Pariwisata Klungkung akan semakin meningkat. Sehingga hipotesis pertama diterima. Hubungan positif dan signifikan antara stres kerja dan kinerja pegawai dapat terjadi karena hampir setiap kondisi pekerjaan menyebabkan stres, tergantung seberapa besar stres yang diterima pegawai dan reaksi dari pegawai. Stres kerja dapat membantu atau merusak kinerja pegawai tergantung seberapa besar tingkat stres itu, bila tidak ada 
stres, tantangan kerja juga tidak ada dan kinerja pegawai menjadi menurun, sebaliknya jika stres meningkat, kinerja pegawai dapat meningkat karena stres kerja membantu pegawai mencapai tugasnya dalam bekerja. Jadi dapat di simpulkan stres kerja dapat meningkatkan dan menurunkan kinerja pegawai tergantung dari seberapa besar tingkat stres tersebut dan reaksi pegawai.

Hal ini sejalan dengan hasil penelitian yang dilakukan oleh Komarudin (2018), Massie \& Areros (2018), Zafar et al. (2015) menemukan hasil yang sama bahwa terdapat hubungan positif signifikan antara stres kerja terhadap kinerja karyawan. Roring \& Dotoulong (2014), Karim (2014) dalam penelitiannya menemukan hasil yang sama bahwa stres kerja secara statistik berpengaruh positif dan signifikan terhadap prestasi kerja karyawan.

Hasil pengujian hipotesis dalam penelitian ini menunjukkan bahwa stres kerja memiliki pengaruh positif dan signifikan terhadap motivasi, dengan kata lain semakin tinggi tingkat stres kerja pegawai di Dinas Pariwisata Klungkung, maka semakin tinggi tingkat motivasi pegawai di Dinas Pariwisata Klungkung. Sehingga Hipotesis kedua diterima. Hubungan positif dan signifikan antara stres kerja dan motivasi terjadi karena stres merupakan kondisi ketegangan yang mempengaruhi emosi, proses berpikir dan kondisi seseorang. Motivasi adalah suatu daya pedorong yang menyebabkan orang berbuat sesuatu. Stres dapat melemahkan atau mengkuatkan motivasi dalam diri pegawai, tergantung dari seberapa besar tingkat stres dan reaksi dari pegawai, motivasi kerja sangat dibutuhkan oleh pegawai sebagai dorongan untuk menciptakan gairah dan semangat kerja.

Hal ini sejalan dengan hasil penelitian yang dilakukan oleh Zeb Alam \& Rehman (2015) menemukan adanya pengaruh positif antara stres kerja terhadap motivasi kerja karyawan. Penelitian dari Noermijati \& Primasari (2015), Pertiwiningsih \& Puspasari (2014), Rendika \& Setyawan (2015), Cendhikia et al. (2016) menemukan hasil yang sama bahwa stres kerja berpengaruh postif dan signifikan terhadap motivasi.

Hasil Pengujian hipotesis dalam penelitian ini menunjukkan bahwa Motivasi memiliki pengaruh positif dan signifikan terhadap kinerja pegawai, dengan kata lain apabila motivasi meningkat maka kinerja pegawai di Dinas Pariwisata Klungkung akan semakin meningkat. Sehingga hipotesis ketiga diterima. Motivasi kerja sangat dibutuhkan oleh pegawai sebagai dorongan untuk menciptakan semangat dan gairah kerja. Untuk dapat memelihara kinerja pegawai dan kepuasan kerja salah satunya adalah dengan memberikan dorongan (motivasi) ke pada pegawai agar mereka dapat melaksanakan tugas sesuai uraian tugas dan pengarahan. Motivasi pada pegawai dapat mengakibatkan tumbuhnya semangat kerja apabila semangat kerja menjadi tinggi maka pekerjaan yang di bebankan kepada pegawai akan lebih cepat dan tepat selesai. Pekerjaan yang dengan cepat dan tepat selesai merupakan suatu prestasi kerja.

Hasil penelitian ini sejalan dengan penelitian yang dilakukan oleh Mohamud et al. (2017), Ali et al. (2016), Ekundayo \& Babalola (2018) menemukan hasil yang sama bahwa terdapat hubungan positif dan signifikan antara motivasi kerja dengan kinerja karyawan. Shahzadi et al. (2015) menemukan bahwa terdapat pengaruh positif antara motivasi kerja dengan kinerja karyawan. Dwiputra \& Satrya (2019) 
menemukan bahwa motivasi kerja berpengaruh signifikan terhadap kinerja karyawan.

Hasil Pengujian hipotesis dalam penelitian ini menunjukkan bahwa motivasi merupakan variabel yang memediasi pengaruh stres kerja terhadap kinerja pegawai di Dinas Pariwisata Klungkung, atau dengan kata lain stres kerja dapat berpengaruh secara tidak langsung melalui motivasi terhadap kinerja pegawai di Dinas Pariwisata Klungkung. Sehingga hipotesis keempat diterima. Pengaruh stres kerja terhadap kinerja pegawai dapat berupa pengaruh tidak langsung. Karena stres kerja mempengaruhi salah satu faktor kinerja yaitu motivasi. Motivasi adalah kondisi psikologis individu yang mendorong individu untuk melakukan sesuatu. Motivasi ini mengakibatkan individu mengerahkan segala kemampuannya untuk melaksanakan tugas dan pekerjaanya. Motivasi kerja sangat dibutuhkan oleh individu sebagai dorongan untuk menciptakan semangat dan gairah kerja. Stres yang berlebihan akan mengakibatkan lemahnya motivasi, motivasi yang lemah dapat mengakibatkan kinerja pegawai yang semakin menurun.

Hasil penelitian ini sejalan dengan hasil penelitian yang dilakukan oleh Mariati (2018), Naradhipa \& Asshuri (2016) menemukan hasil yang sama bahwa stres kerja mempengaruhi kinerja karyawan melalui motivasi kerja sebagai variabel intervening. Noermijati \& Primasari (2015), Cendhikia et al. (2016), Maulidyah (2017) menemukan hasil yang sama bahwa stres kerja berpengaruh positif dan signifikan terhadap motivasi dan kinerja karyawan.

Implikasi teoritis dari hasil penelitian ini memberikan bukti pada pengembangan ilmu perilaku keorganisasian dan sumber daya manusia khususnya mengenai stres kerja, motivasi dan kinerja pegawai. Selain itu hasil penelitian ini secara praktis dapat menjadi salah satu acuan bagi peneliti lainnnya yang ingin meneliti mengenai stres kerja, motivasi dan kinerja pegawai. Secara teoritis penelitian ini juga memberikan pemahaman bahwa stres kerja dan motivasi secara nyata dapat meningkatkan kinerja pegawai, ketika stres yang dirasakan oleh pegawai menguatkan motivasi, maka motivasi yang dirasakan oleh pegawai menjadi semakin kuat sehingga berpotensi meningkatkan kinerja pegawai di Dinas Pariwisata Klungkung.

\section{SIMPULAN}

Stres kerja berpengaruh positif dan signifikan terhadap kinerja pegawai di Dinas Pariwisata Klungkung. sehingga hipotesis 1 diterima. Hal ini menunjukan bahwa jika stres kerja meningkat maka kinerja pegawai di Dinas Pariwisata Klungkung akan meningkat. Stres kerja berpengaruh positif dan signifikan terhadap motivasi di Dinas Pariwisata Klungkung, sehingga hipotesis 2 diterima. Hal ini menunjukan bahwa jika stres kerja meningkat maka motivasi pegawai di Dinas Pariwisata Klungkung semakin kuat. Motivasi berpengaruh positif dan signifikan terhadap kinerja pegawai di Dinas Pariwisata Klungkung. sehingga hipotesis 3 diterima. Hal ini menunjukan bahwa jika motivasi semakin kuat maka kinerja pegawai di Dinas Pariwisata Klungkung akan meningkat. Motivasi merupakan variabel mediasi antara pengaruh stres kerja terhadap kinerja pegawai 
di Dinas Pariwisata Klungkung. sehingga hipotesis 4 diterima. Hal ini menunjukan bahwa pengaruh stres kerja terhadap kinerja pegawai di Dinas Pariwisata Klungkung dapat berupa pengaruh tidak langsung melalui motivasi.

Pimpinan di Dinas Pariwisata Klungkung sebaiknya lebih memperhatikan rencana kerja pegawai, agar rencana kerja yang telah direncanakan berjalan optimal. Hal ini di dasarkan pada jawaban responden tentang variabel kinerja pegawai yang memiliki nilai rata - rata terendah adalah pernyataan "Rencana kerja saya berjalan optimal " ini berarti secara umum rencana kerja responden belum berjalan optimal. Pimpinan hendaknya dapat memberikan pengarahan kepada pegawai agar rencana kerja yang telah di rencanakan berjalan dengan optimal, dengan begitu kinerja pegawai semakin membaik dan Dinas Pariwisata Klungkung akan dapat mencapai tujuanya dengan efektif dan efisien.

Pimpinan di Dinas Pariwisata Klungkung sebaiknya memberikan perhatian lebih terhadap pegawai guna meningkatkan kinerjanya seperti meningkatkan kuantitas dan kualitas pengawasan serta pelatihan dan pengembangan SDM agar saat pegawai mengerjakan tugasnya dapat meminimalkan tingkat kesalahan dalam mengerjakan tugas. Hal ini di dasarkan pada jawaban responden tentang motivasi yang memiliki nilai rata - rata terendah yaitu pernyataan "Saat saya melakukan kesalahan dalam melakukan pekerjaan, saya akan berinisiatif memperbaiki menjadi lebih baik", ini berarti secara umum responden menganggap saat responden melakukan kesalahan dalam melakukan pekerjaan, responden tidak berinisiatif memperbaiki menjadi lebih baik. Pimpinan di Dinas Pariwisata Klungkung sebaiknya dapat memberikan perhatian lebih khususnya kepada faktor - faktor penyebab stres kerja, seperti lingkungan kerja, beban kerja yang diberikan, penyebab stres antar pribadi, dan lain - lain agar tidak menggangu kinerja pegawai. Hal ini berdasarkan pada jawaban responden tentang stres kerja yang memiliki nilai rata-rata terendah yaitu pernyataan "Saya mampu menyelesaikan pekerjaan dengan tepat waktu", berarti secara umum responden menganggap belum mampu menyelesaikan pekerjaan dengan tepat waktu.

Bagi penelitian selanjutnya diharapkan mampu mengkaji lebih banyak sumber dan refrensi terkait dengan variabel penelitian serta mempertimbangkan variabel - variabel lain khususnya yang mempengaruhi kinerja pegawai. Serta mampu untuk memperluas ruang lingkup penelitian yang tidak hanya terbatas di Dinas Pariwisata Klungkung, atau dapat juga mengganti lokasi penelitian yang tidak hanya terfokus pada satu lokasi penelitian, sehingga memberikan suatu pandangan yang lebih dan mampu di implementasikan secara umum. 


\section{REFERENSI}

Ali, A., Bin, L. Z., Piang, H. J., \& Ali, Z. (2016). The Impact of Motivation on the Employee Performance and Job Satisfaction in IT Park (Software House) Sector of Peshawar, Pakistan. International Journal of Academic Research in Business and Social Sciences, 6(9), 297-310. https://doi.org/10.6007/ijarbss/v6-i9/2311

Arrasyid, M. I., Glorino, M., \& Pandin, R. (2019). Review on Leader Member Exchange Theory: Antecedent and The Effect on Employee Performance. Preprints, 1(5), 1-21.

Asim, M. (2013). Impact of Motivation on Employee Perfomance with Effect of Training: Specific to Education Sector of Pakistan. International Journal of Sceientific and Research Publications, 3(9), 1-9.

Cemal, Z., Muceldili, B., \& Sehir, S. (2012). The Moderating Effect of Ethical Climate on the Relationship between Job Satisfaction and Organizational Commitment: Evidence from Large Companies in Turkey. Journal Social and Behavioral Sciences, 5(8), 734-743.

Cendhikia, D. B., Nayati, U. H., \& Prasetya, A. (2016). Pengaruh Konflik Kerja dan Stres Kerja Terhadap Motivasi Kerja Karyawan dan Kinerja Karyawan. (Studi pada Karyawan PT.Telekomunikasi Indonesia, Tbk Witel Jatim Selatan). Jurnal Administrasi Bisnis (JAB), 35(2), 136-145.

Cropanzano, R., Anthony, E. L., Daniels, S. R., \& Hall, A. V. (2017). Social exchange theory: A critical review with theoretical remedies. Academy of Management Annals, 11(1), 479-516. https://doi.org/10.5465/annals.2015.0099

Diputra, A. A. D. P., \& Surya, I. B. K. (2019). Pengaruh Stress Kerja terhadap kinerja Karyawan dimediasi oleh kepuasaan kerja karyawan PT. Destination Asia Bali. E-Jurnal Manajemen Unud, 8(2), 7986-8015.

Dwiputra, I. K. A., \& Satrya, I. G. B. H. (2019). Pengaruh Kepemimpinan, Motivasi, dan Iklim Organisasi Terhadap Kinerja Karyawan di Warung Mina Peguyangan Denpasar. E-Jurnal Manajemen Unud, 8(1), 2918 - 2943.

Ekundayo, O. A., \& Babalola, J. A. (2018). The Impact of Motivation on Employee Performance in Selected Insurance Companies in Nigeria. International Journal of African Development, 5(1), 31-42.

Giantari, I. A. I., \& Riana, I. G. (2017). Pengaruh Budaya Organisasi Terhadap Motivasi Kerja dan Kinerja Karyawan Klumpu Bali Resorts Sanur. E-Jurnal Manajemen Unud, 6(12), 6471-6498.

Hariasih, M., \& Fahmi, A. (2016). Pengaruh Motivasi, Pengalaman Kerja Dan Lingkungan Kerja Terhadap Prestasi Kerja Guru SMK Muhammadiyah 1 Ngoro Jombang. Jurnal Bisnis, Manajemen \& Perbankan, 2(2), 121 - 140. 
Ijah. (2013). The Influence Of Motivation On Employees Performance. Ajol, 2(1), 2227. Retrieved from http://www.ajol.info/index.php diakses 19 April 2019)

Karim, N. (2014). Stres Kerja Pengaruhnya terhadap Prestasi Kerja pada Karyawan Cafe Bambu Express Manado. Jurnal Emba, 1(4), 513-522.

Komarudin. (2018). Hubungan Stres Kerja Dengan Kinerja Pegawai Pada Ptherona Express Kantor Pusat Pamulang. Jurnal Ilmiah Kreatif, 6(2), 53-65.

Koopmans, L., Bernaards, C. M., Hildebrandt, V. H., Vet, H. C. W. D., \& Beek, A. V. D. (2015). Construct Validity of the Individual work performance questionnarie. Journal Of Occupational Dan Environmental Medicine, 56(3), 331-337.

Kotteeswari, M., \& Sharief, S. T. (2015). Job Stress And Its Impact On Performance Employees Working In BPOS. International Journal of Advanced Research in Management, 5(2), 19-27.

Kurniawan, D. (2012). Pengaruh Budaya Kerja dan Motivasi Kerja Terhadap Kinerja Karyawan (IFRC) Banda Aceh. Jurnal Manajemen Pascasarjana Universitas Syiah Kuala, 1(1), 1-15.

Larasati, S., \& Gilang, A. (2014). Pengaruh Motivasi Kerja Terhadap Kinerja Karyawan Wilayah Telkom Jabar Barat Utara ( Witel Bekasi ). Jurnal Manajemen Dan Organisasi, 5(1), 1-12.

Mardyana, I. K. E., \& Riana, I. G. (2019). Peran Komitmen Organisasional Dalam Memediasi Pengaruh Kepuasan Kerja Terhadap Kinerja Karyawan Krisna Oleh - Oleh Khas Bali I. E-Jurnal Manajemen Universitas Udayana, 1(1), 120 .

Mariati, M. H. (2018). The Influence of Organizational Culture And Work Motivation on Employee Performance, Job Satisfaction As Intervening Variable ( Study On Secretariat Staff of Pasuruan Regency ). IOSR Journal of Business and Management, 20(8), 30-39. https://doi.org/10.9790/487X2008013039

Massie, R. N., \& Areros, W. A. (2018). Pengaruh Stres Kerja Terhadap Kinerja Karyawan Pada Kantor Pengelola IT Center Manado. Jurnal Administrasi Bisnis, 6(002), 41-49.

Maulidyah, I. A. (2017). Pengaruh Stress Kerja Terhadap Kinerja Karyawan Back Office dengan Motivasi sebagai Variabel Intervening pada PT. Bank Tabungan Negara (persero), TBK Kantor Cabang Surabaya. Jurnal Ilmu Manajemen, 3(5), 1-9.

Mohamud, A., Ibrahim, A. A., \& Hussein, J. M. (2017). The Effect of Motivation on Employee Performance : Case Study in Hormuud Company in Mogadishu Somalia. International Journal of Development Research, 07(11), 1700917016. 
Naradhipa, H. D., \& Asshuri, M. (2016). Pengaruh Stres Kerja Terhadap Motivasi Kerja Dan Dampaknya Terhadap Kinerja Karyawan (Studi Pada Pengemudi di PT. Citra Perdana Kendedes). Jurnal Ilmiah Mahasiswa FEB Universitas Brawijaya, 3(2), 1-20.

Nazir, S., Qun, W., Hui, L., \& Shafi, A. (2018). Influence of social exchange relationships on affective commitment and innovative behavior: Role of perceived organizational support. Sustainability (Switzerland), 10(12), 1-12. https://doi.org/10.3390/su10124418

Noermijati, N., \& Primasari, D. (2015). The effect of job stress and job motivation on employees' performance through job satisfaction (A study at PT. Jasa Marga (Persero) Tbk. Surabaya - Gempol branch). Journal of Economics, Business \& Accountancy Ventura, 18(2), 231. https://doi.org/10.14414/jebav.v18i2.450

Notanubun, M. S., Adolfina, \& Djemly, W. (2019). Pengaruh Stres Kerja Dan Kepuasan Kerja Terhadap Kinerja Pegawai Pada Kejaksaan Negeri Manado. Jurnal EMBA: Jurnal Riset Ekonomi, Manajemen, Bisnis Dan Akuntansi, 7(1), 681-690.

Pertiwiningsih, H. R., \& Puspasari, D. (2014). Pengaruh Stres Kerja terhadap Motivasi Kerja Karyawan di PT. Telkom Surabaya Metro. Jurnal Administrasi Perkantoran (JPAP), 2(2), 1-20.

Putra, P. W. G. S., \& Suwandana, I. G. M. (2018). Pengaruh Motivasi, Gaya Kepemimpinan Transformasional, Dan Lingkungan Kerja Fisik Terhadap Semangat Kerja Pegawai Bappeda Litbang Provinsi Bali. E-Jurnal Manajemen Universitas Udayana, 1(1), 1-20.

Rahmanto, \& Helina. (2017). Pengaruh Prestasi Kerja Terhadap Kinerja Karyawan PT. Retail bandung. Jurnal Akuntansi Dan Manajemen SocioPreneur, 1(2), $1-10$.

Ratnawat, R. ., \& Jha, D. P. . (2014). Impact of Job Related Stress on Employee Performance: A Review and Research Agenda. IOSR Journal of Business and Management, 16(11), 01-06. https://doi.org/10.9790/487x-161150106

Rendika, I. S., \& Setyawan, A. A. (2015). Analisis pengaruh stress kerja terhadap Motivasi Kerja Pegawai PT. Adira Finance Solo. Jurnal Universitas Muhamadiyah Surakarta, 1(1), 1-20.

Roring, M. Y., \& Dotoulong, L. (2014). Stres Kerja dan Lingkungan Kerja pengaruhnya tehadap Prestasi Pegawai pada Biro Umum Setda Provinsi Sulawesi Utara. Jurnal EMBA, 2(3), 1359-1368.

Shahzadi, I., Javed, A., Pirzada, S. S., Nasreen, S., \& Khanam, F. (2015). Impact of Employee Motivation on Employee Performance. European Journal of Business and Management, 6(23), 159-167.

Sumaryati, Y. (2009). Menerapkan Prinsip Profesional Bekerja. Bandung: Armico. 
Walden, J. A., Catherine, Y., \& Westerman, K. (2018). Strengthening the Tie: Creating Exchange Relationships That Encourage Employee Advocacy as an Organizational Citizenship Behavior. SAGE Journal, 1(1), 1-20. https://doi.org/https://doi.org/10.1177/0893318918783612

Widyasari, M. (2013). Hubungan sikap karyawan dengan Motivasi kerja dan prestasi kerja. Jurnal Manajemen, Strategi Bisnis, Dan Kewirausahaan, 7(58), 57-65.

Zafar, Q., Ali, A., Hameed, T., Ilyas, T., \& Younas, H. I. (2015). The Influence of Job Stress on Employes Perfomance in Pakistan. American Journal of Social Science Research, 1(4), 221-225.

Zameer, H., Ali, S., Nisar, W., \& Amir, M. (2015). The Impact Of The Motivation on The Employee ${ }^{e e}$ Performance in Beverage Industry Of Pakistan. Journal Of Academic Research in Accounting, Finance and Management Sciences, 4(1), 293-298.

Zeb Alam, G. S., \& Rehman, S. (2015). The Impact of Job Stress on Employee's Performance: Investigating The Moderating Effect of Employees Motivation. City University Research Journal, 5(1), 120-129. 